\title{
Calenduloside E 6'-methyl ester induces apoptosis in CT-26 mouse colon carcinoma cells and inhibits tumor growth in a CT-26 xenograft animal model
}

\author{
BORA LEE, DAE YOUNG LEE, KI HYUN YOO, NAM IN BAEK, JONG-HWA PARK and IN SIK CHUNG \\ Department of Genetic Engineering and Graduate School of Biotechnology, \\ Kyung Hee University, Yongin 446-701, Republic of Korea
}

Received January 16, 2012; Accepted March 28, 2012

DOI: $10.3892 / \mathrm{ol} .2012 .693$

\begin{abstract}
The aim of the present study was to investigate the cytotoxic effect of calenduloside E 6'-methyl ester (oleanolic acid 3-O- $\beta$-D-glucuronopyranoside-6'-methyl ester) isolated from Acanthopanax sessiliflorus fruits was investigated in CT-26 mouse colon carcinoma cells. Calenduloside E 6'-methyl ester dose-dependently inhibited the viability of CT-26 cells. Apoptosis was characterized by the detection of annexin-V and sub-G1 apoptotic cell populations, terminal deoxynucleotidyl transferase dUTP nick end labeling (TUNEL) and DNA fragmentation experiments. Results showed that the number of immunostained annexin-V-FITC and sub-G1 cells increased after treatment with calenduloside E 6'-methyl ester. Calenduloside E 6'-methyl ester also increased terminal deoxynucleotidyl transferase dUTP nick end labeled-CT-26 cells. It induced DNA fragmentation. and the cleavage of caspase-8, -9, -3 and poly ADP-ribose polymerases. In addition, calenduloside E 6'-methyl ester suppressed the volume and weight of tumors in BALB/c mice subcutaneously implanted with CT-26 cells. These results indicate that calenduloside E 6'-methyl ester induces apoptosis in CT-26 mouse colon carcinoma cells and inhibits tumor growth in a CT-26 carcinoma animal model.
\end{abstract}

\section{Introduction}

Several cancer treatment strategies, including surgery, chemotherapy and radiation therapy, have been developed to treat cancer and cancer-related diseases. Among these treatments, chemoprevention and chemotherapy using natural compounds

Correspondence to: Dr In Sik Chung or Dr Jong-Hwa Park, Department of Genetic Engineering and Graduate School of Biotechnology, Kyung Hee University, Yongin 446-701, Republic of Korea

E-mail: ischung@khu.ac.kr

E-mail:phdpark@khu.ac.kr

Key words: apoptosis, calenduloside E 6'-methyl ester, CT-26, mouse colon carcinoma have been found to effectively prevent the progression of cancer. Although various types of cancer initially respond to chemotherapy, the development of chemotherapy resistance continues to be the main problem in the treatment of cancer. Therefore, new agents demonstrating chemotherapeutic and chemopreventive activities should be identified.

Triterpenoids are a large family of natural compounds commonly found in a diversity of plants (1-3). Certain natural triterpenoids, including oleanolic acid ( $3 \beta$-hydroxyolean-12-en-28-oic acid) and its isomer ursolic acid (3ß-hydroxy-urs-12-en-28-oic acid), possess anti-cancer and anti-inflammatory activities (4-7). Moreover, results of previous studies showed that several synthetic triterpenoid compounds derived from oleanolic acid including 2-cyano3,12-dioxooleana-1,9(11)-dien-28-oic acid (CDDO) and its methyl ester (CDDO-Me) derivative possess significant anti-tumorigenic and anti-inflammatory activity (8-11). Triterpenoids have also been known to prevent oxidative stress, inflammation and hypertension (12).

Calenduloside E 6'-methyl ester (oleanolic acid 3-O- $\beta$-Dglucuronopyranoside-6'-methyl ester) is a naturally occurring oleanane-type triterpenoid. Calenduloside E6'-methyl ester was isolated from the Brazilian ginseng, Pfaffia paniculata (13), but can also be obtained from Acanthopanax sessiliflorus (A. sessiliflorus). A. sessiliflorus, an Acanthopanax species that occurs in abundance in Korea, belongs to the herbaceous type of Araliaceae. The shoots and roots of diverse species of Acanthopanax have traditionally been used as medicines for a number of diseases, including diabetes, neuralgia, palsy, gastric ulcer, learning-behavior difficulties and cancer (14-16).

To the best of our knowledge, neither the biological activities of calenduloside E 6'-methyl ester nor its effect on cancer cells have been reported. Thus, we isolated calenduloside $\mathrm{E}$ 6'-methyl ester from A. sessiliflorus fruits and examined the anti-cancer activity in mouse colon carcinoma CT-26 cells. In addition, the anti-tumor activity of calenduloside E 6'-methyl ester was evaluated in a CT-26 colon carcinoma animal model.

\section{Materials and methods}

Extraction and isolation of calenduloside E 6'-methyl ester. The air-dried fruit of A.sessiliflorus (10 kg) was powdered and 
extracted with 36 litres of aqueous $70 \% \mathrm{EtOH}$ at room temperature for $3 \times 24 \mathrm{~h}$. After concentration, the EtOH extract $(2,012 \mathrm{~g})$ was suspended in $\mathrm{H}_{2} \mathrm{O}$ and then partitioned successively with EtOAc, n-BuOH and $\mathrm{H}_{2} \mathrm{O}$ to produce EtOAc (E, $\left.118 \mathrm{~g}\right)$, $\mathrm{n}-\mathrm{BuOH}(\mathrm{B}, 284 \mathrm{~g})$ and water fractions, respectively. Fraction $\mathrm{B}$ was chromatographed on a column of highly porous polymer (Diaion HP-20) and eluted with $\mathrm{H}_{2} \mathrm{O}$ and $\mathrm{MeOH}$, respectively, to yield two fractions (B1 and B2). Fraction B2 (73.40 g) was subjected to silica gel column $(12 \times 13 \mathrm{~cm})$ chromatography (c.c.) using a gradient of $\mathrm{CH}_{3} \mathrm{Cl}_{3}: \mathrm{MeOH}: \mathrm{H}_{2} \mathrm{O}(7: 3: 1 \rightarrow 65: 35: 10$, 4 litres of each) to yield 11 major fractions (B2-1 to B2-11). Fraction B2-4 [3.50 g, Ve/Vt (elution volume/total volume), $0.41-0.57]$ was subjected to RP-18 c.c. $\left[(12 \times 13 \mathrm{~cm})\left(\mathrm{MeOH}: \mathrm{H}_{2} \mathrm{O}\right.\right.$, $1.5: 1 \rightarrow 2: 1 \rightarrow 4: 1)]$ to produce six subfractions (B2-4-1 to B2-4-6). Subfraction B2-4-6 (1.44 g, Ve/Vt 0.76-0.99) was purified over $\mathrm{SiO}_{2}$ c.c. $(4.5 \times 15 \mathrm{~cm})$ and eluted with $\mathrm{CH}_{3} \mathrm{Cl}_{3}-\mathrm{MeOH}-\mathrm{H}_{2} \mathrm{O}$ (13:3:1) to yield calenduloside E 6'-methyl ester [88 mg, TLC $\left(\mathrm{SiO}_{2} \mathrm{~F} 254\right) \mathrm{Rf} 0.60$ in $\mathrm{CH}_{3} \mathrm{Cl}_{3}: \mathrm{MeOH}: \mathrm{H}_{2} \mathrm{O}$ (65:35:10)].

Cell line and culture condition. Mouse colon carcinoma CT-26 cells were obtained from the Korean Cell Line Bank (KCLB; Seoul, Korea) and grown at $37^{\circ} \mathrm{C}$ with $5 \% \mathrm{CO}_{2}$ in Dulbecco's modified Eagle's medium (DMEM) with $10 \%$ fetal bovine serum (FBS) and $1 \%$ penicillin/streptomycin. Cell culture medium and reagents were purchased from Thermo Scientific Hyclone (Waltham, MA, USA).

Cytotoxicity assay. The cytotoxicity of calenduloside E 6'-methyl ester was measured using the MTT [3-(4,5-dimethylthiazol-2-yl)-2,5-diphenyltetrazolium bromide] (Sigma, St. Louis, MO, USA) colorimetric assay. CT-26 cells were seeded onto 96-well plates at a density of $1 \times 10^{4}$ cells/well in $100 \mu \mathrm{l}$ of DMEM supplemented with $10 \% \mathrm{FBS}$. After $24 \mathrm{~h}$ of incubation at $37^{\circ} \mathrm{C}$, cells were treated with serum-free DMEM containing various concentrations of calenduloside $\mathrm{E}$ 6'-methyl ester. After $24 \mathrm{~h}$ of incubation, $50 \mu \mathrm{l}$ of MTT (5 mg/ $\mathrm{ml}$ in PBS) was added to each well. Cells were incubated at $37^{\circ} \mathrm{C}$ for $2 \mathrm{~h}$. After removal of the medium, cells were treated with $100 \mu$ l of dimethyl sulfoxide (DMSO) for $5 \mathrm{~min}$, and then the optical density was measured using a microplate reader (Bio-Tek, Winooski, VT, USA) at $550 \mathrm{~nm}$. Cell viability was calculated as the percentage of viable cells in the calenduloside E 6'-methyl ester-treated group $(2.5,5,10,15,20$ and $25 \mu \mathrm{M})$ versus the control group using the equation: Cell viability (\%) $=\left[\left(\mathrm{OD}_{\text {Compound }}-\mathrm{OD}_{\text {Blank }}\right) /\left(\mathrm{OD}_{\text {Contol }}-\mathrm{OD}_{\text {Blank }}\right)\right] \mathrm{x} 100$.

Cell cycle analysis. CT-26 cells were seeded onto 6-well plates at a density of $3 \times 10^{5}$ cells/well in $2 \mathrm{ml}$ of DMEM supplemented with $10 \% \mathrm{FBS}$. After $24 \mathrm{~h}$ of incubation at $37^{\circ} \mathrm{C}$, cells were treated with serum-free DMEM containing different concentrations of calenduloside E 6'-methyl ester. After $12 \mathrm{~h}$ of incubation, cells were collected and washed twice with ice-cold PBS. Cell pellets were fixed in $70 \%$ cold ethanol overnight at $-20^{\circ} \mathrm{C}$. Fixed cells were centrifuged, washed and resuspended in $100 \mu \mathrm{l}$ of PBS, then mixed with $100 \mu \mathrm{l}$ of RNase A $(1 \mathrm{mg} / \mathrm{ml}$; Sigma) and incubated for $30 \mathrm{~min}$ at $37^{\circ} \mathrm{C}$. The cells were stained by adding $400 \mu \mathrm{l}$ of propidium iodide (PI, $50 \mu \mathrm{g} / \mathrm{ml}$; Sigma). After filtering through a nylon mesh $(40 \mu \mathrm{m})$, the DNA content of the stained cells was analyzed using the FACSVantage SE and CellQuest program (BD Biosciences, San Jose, CA, USA).
Annexin V staining assay. Modulation of phosphatidylserine externalization during apoptosis was assessed using annexin $\mathrm{V}$ conjugated with the fluorescent dye fluorescein isothiocyanate (FITC). CT-26 cells were seeded onto 6-well plates at a density of $3 \times 10^{5}$ cells/well and incubated for $24 \mathrm{~h}$. After treatment with serum-free DMEM containing $10 \mu \mathrm{M}$ calenduloside E 6'-methyl ester for $6 \mathrm{~h}$, cells were stained with the annexin V-FITC conjugate, and images were captured at an objective magnification of x40 using a confocal laser scanning microscope (LSM 510 Meta, Carl Zeiss, Oberkochen, Germany).

Terminal deoxynucleotidyl transferase mediated dUTP nick end labeling (TUNEL) assay. TUNEL staining was performed on calenduloside E 6'-methyl ester-treated CT-26 cells using an in situ cell death detection kit (Roche, Basel, Switzerland). Briefly, cells were fixed with $4 \%$ paraformaldehyde and permeabilized with $0.1 \%$ Triton $\mathrm{X}-100$ in $0.1 \%$ sodium citrate buffer. Fixed and permeabilized cells were stained with enzyme buffer containing terminal deoxynucleotidyl transferase (TdT) and fluorescein-dUTP. Following washes, the nuclei were stained with a PI $(2 \mu \mathrm{g} / \mathrm{ml})$ solution for $1 \mathrm{~min}$. Cells were imaged under $\mathrm{x} 40$ objective magnification using a confocal laser scanning microscope.

DNA fragmentation assay. Genomic DNA was isolated from calenduloside E 6'-methyl ester-treated CT-26 cells using a DNA Mini kit (Qiagen, Hilden, Germany) according to the manufacturer's instructions. The isolated genomic DNA samples were electrophoresed on a $1.5 \%$ agarose gel at $50 \mathrm{~V}$ for $1 \mathrm{~h}$. The gel was stained with ethidium bromide (EtBr; Sigma) and visualized using a UV transilluminator (Wealtech, Reno, NV, USA).

Western blot analysis. After seeding onto 6-well plates at a density of $3 \times 10^{5}$ cells/well and incubating for $24 \mathrm{~h}$, cells were treated with $10 \mu \mathrm{M}$ calenduloside E 6'-methyl ester for various times up to $12 \mathrm{~h}$. The cells were then lysed with RIPA buffer (Thermo Fisher Scientific Inc., Rockford, IL, USA) supplemented with a protease inhibitor cocktail (Roche, Mannheim, Germany). Protein concentrations were determined using an RC/DC Bio-Rad assay kit (Bio-Rad, Hercules, CA, USA) following the manufacturer's instructions. Protein samples were separated by electrophoresis on $10-15 \%$ sodium dodecyl sulfate (SDS)-polyacrylamide gels. The proteins on the gel were transferred onto a polyvinylidene fluoride (PDVF) membrane (PALL Life Science, Port Washington, NY, USA), blocked with 5\% skimmed milk (BD Biosciences), incubated with an anti-mouse caspase-3, -8, -9 and poly ADP-ribose polymerase (PARP) (Cell Signaling Technology Inc., Danvers, MA, USA), and anti-mouse actin (Sigma). The membrane was then probed with the horseradish peroxidase-conjugated antirabbit IgG (GE Healthcare Life Sciences, Stockholm, Sweden). Protein bands were detected using an enhanced chemiluminescent western blotting detection system (GE Healthcare Life Sciences).

Tumor growth in CT-26 allograft bearing mice. Five-week-old female BALB/c mice were purchased from Orient Bio Inc. (Seongnam, Korea). The mice were provided with water and food ad libitum, and were quarantined in a specific pathogen- 
A

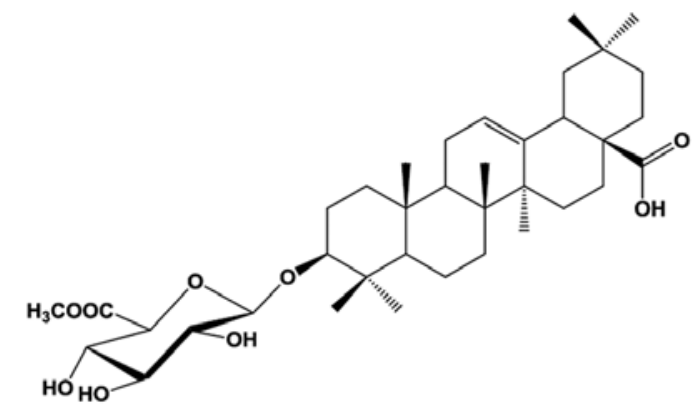

B

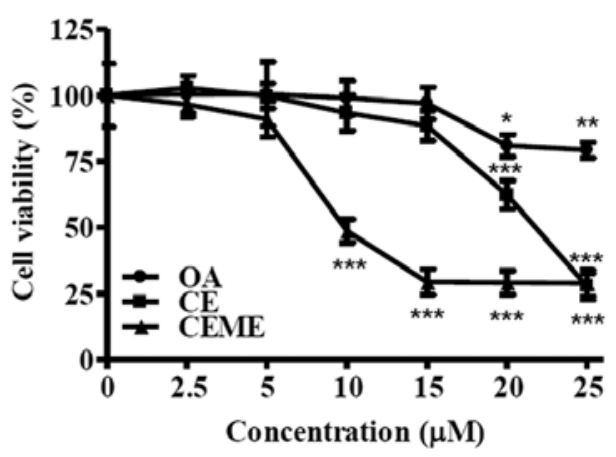

Figure 1. Structure of calenduloside E 6'-methyl ester and cytotoxicity analysis of calenduloside E 6'-methyl ester-treated CT-26 cells. (A) Structure of calenduloside E 6'-methyl ester isolated from Acanthopanax sessiliflorus fruits. (B) Effect of calenduloside E 6'-methyl ester on the cell viability of CT-26 cells. The cells were treated with various concentrations of calenduloside E 6'-methyl ester and its variants OA and CE for 24 h and cell viabilities were determined using the MTT assay. OA, oleanolic acid; CE, calenduloside E; CEME, calenduloside E 6'-methyl ester. Data are shown as the mean \pm SD of triplicate experiments. Statistically significant differences between treated and control cells were determined using the Student's t-test $\left({ }^{*} \mathrm{p}<0.05,{ }^{* *} \mathrm{p}<0.01\right.$, **** $\mathrm{p}<0.001)$. SD, standard deviation.

free environment with a $12 \mathrm{~h}$ light/dark photoperiod in an animal care facility accredited by the Kyung Hee University Institutional Animal Care and Use Committee. Animal care and experimental procedures followed the Kyung Hee University guidelines for the care and use of laboratory animals.

To establish an allograft colon carcinoma animal model, $5 \times 10^{5}$ CT-26 cells in $200 \mu \mathrm{l}$ PBS were injected into the right flank of BALB/c mice. The tumors were allowed to grow into visible masses for 7 days, after which animals were divided into groups of 5 mice each. Each group was treated daily with a peritumor injection of either calenduloside E 6'-methyl ester [0.6, $6 \mathrm{mg} / \mathrm{kg} / \mathrm{day}$ in PBS with $0.2 \%$ DMSO (v/v)] or control (PBS with $0.2 \%$ DMSO) for 8 days. Tumor volumes were measured every other day with a caliper and calculated according to the formula: Length $\mathrm{x}$ width ${ }^{2} \mathrm{x} 0.5$, where length is the largest tumor diameter and width the smallest tumor diameter (17). The mice were sacrificed 15 days after tumor inoculation, and the tumors were excised and weighted.

Statistical analysis. Data are shown as the mean \pm standard deviation (SD) or standard error (SE). The Student's t-test was used to compare different data groups $(\mathrm{p}<0.05, \mathrm{p}<0.01$, $\mathrm{p}<0.001)$.

\section{Results}

Calenduloside E 6'-methyl ester demonstrated dose-dependent cytotoxic effects. We isolated calenduloside E 6'-methyl ester from A. sessiliflorus fruits (Fig. 1A). Identification of the structure was confirmed on the basis of several spectroscopic analyses, including IR, ${ }^{1} \mathrm{H}$ - and ${ }^{13} \mathrm{C}-\mathrm{NMR}$ and $2 \mathrm{D}-\mathrm{NMR}$ (COSY, HSQC, and HMBC) (data not shown). To determine the cytotoxic effect of calenduloside E 6'-methyl ester on CT-26 cells, cells were treated with different concentrations $(2.5,5,10,15,20$ and $25 \mu \mathrm{M})$ of calenduloside E 6'-methyl ester for $24 \mathrm{~h}$ and cell viabilities were measured using an MTT assay. For comparison to its aglycone structure, oleanolic acid, and its parental structure, calenduloside E, CT-26 cells were also treated with oleanolic acid and calenduloside $\mathrm{E}$ at different concentrations $(2.5,5,10,15,20$ and $25 \mu \mathrm{M})$ for $24 \mathrm{~h}$. Calenduloside E 6'-methyl ester dose-dependently inhibited the viability of CT-26 cells (Fig. 1B). The $\mathrm{IC}_{50}$ (50\% growth inhibitory concentration) value of calenduloside E 6'-methyl ester was approximately $10 \mu \mathrm{M}$. The $\mathrm{IC}_{50}$ value of calenduloside $\mathrm{E}$ was between 20 and $25 \mu \mathrm{M}$. However, oleanolic acid was demonstrated to have a low cytotoxicity.

Calenduloside E 6'-methyl ester induced apoptosis in CT-26 cells. To analyze whether the cytotoxic effect of calenduloside E 6'-methyl ester was caused by apoptosis, calenduloside $\mathrm{E}$ 6'-methyl ester-treated CT-26 cells were stained with the annexin V-FITC conjugate, and monitored under confocal microscopy (Fig. 2A and B). Cells treated with calenduloside E 6'-methyl ester were readily stained with annexin V-FITC; however, this was not observed for the untreated control group. The cell cycle was also analyzed to examine the effect of treatment on the sub-G1 apoptotic population of CT-26 cells. Cells were treated with diverse concentrations $(2.5,5,10$ and $25 \mu \mathrm{M})$ of calenduloside E 6'-methyl ester for $12 \mathrm{~h}$ and their DNA contents were analyzed by flow cytometry after PI staining. The number of cells in the sub-G1 population increased in a dose-dependent manner (Fig. 2C and D). After $12 \mathrm{~h}$ of incubation with concentrations of $2.5,5,10$ and $25 \mu \mathrm{M}$, the number of cells in the sub-G1 populations increased to 5.1, $6.4,53.1$ and $99.1 \%$, respectively.

Apoptosis was characterized by TUNEL and a DNA fragmentation assay. Calenduloside E 6'-methyl ester-treated CT-26 cells were labeled with fluorescein-dUTP, and monitored under confocal microscopy (Fig. 3A and B). Fluorescein-labeled cells were observed after $12 \mathrm{~h}$ of incubation with calenduloside E 6'-methyl ester, but not with the control cells. The DNA fragmentation assay was also performed to evaluate genomic DNA fragmentations in calenduloside E 6'-methyl estertreated CT-26 cells. Genomic DNA was purified from cells treated with $10 \mu \mathrm{M}$ calenduloside E 6'-methyl ester for the indicated times $(3,6,9$ and $12 \mathrm{~h})$ and subjected to agarose gel electrophoresis to assess DNA fragmentation (Fig. 3C). DNA fragmentations were observed in calenduloside E 6'-methyl 
A
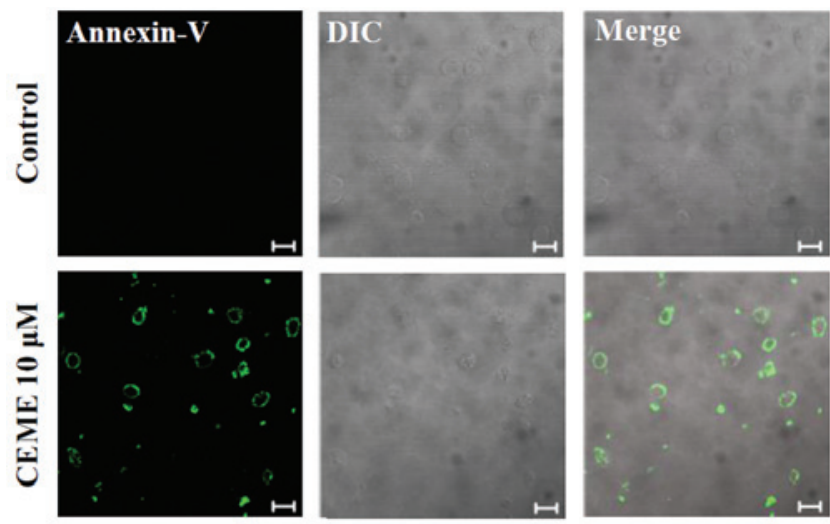
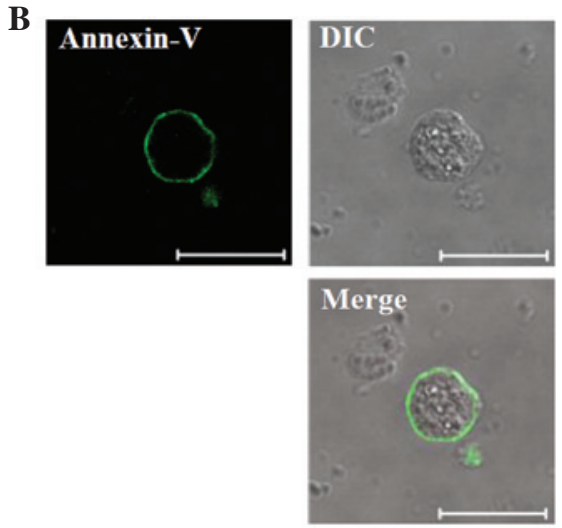

C

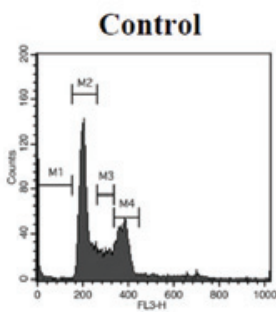

CEME $2.5 \mu \mathrm{M}$

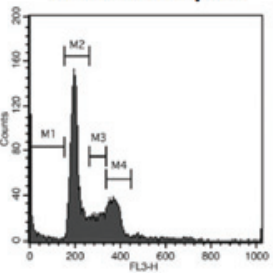

D
CEME $5 \mu \mathrm{M}$
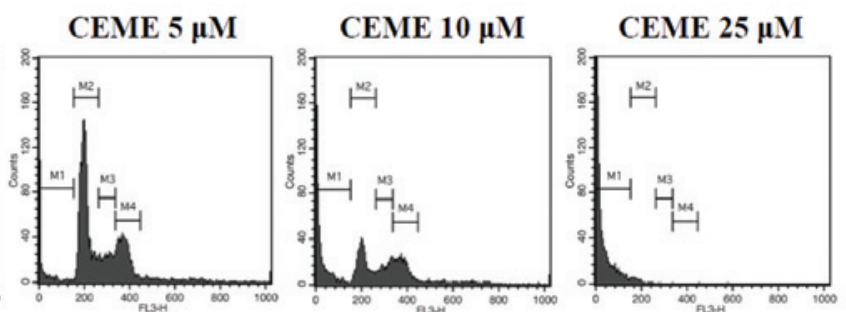

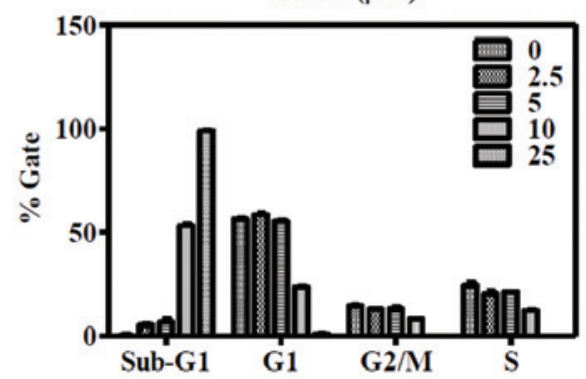

Figure 2. Annexin V and flow cytometric analysis of calenduloside E 6'-methyl ester-treated CT-26 cells. (A) Calenduloside E 6'-methyl ester increased the number of apoptotic cells stained with annexin-V-FITC. Cells were treated with $10 \mu \mathrm{M}$ calenduloside E 6 '-methyl ester for $6 \mathrm{~h}$ and stained with annexin-V-FITC, then imaged under x40 objective magnification using a confocal microscope (bar, $20 \mu \mathrm{m}$ ). DIC, differential interference contrast. (B) Image of the annexinV-FITC-stained cells of (A) is enlarged to better demonstrate the FITC signal (bar, $20 \mu$ m). (C) Calenduloside E 6'-methyl ester increased sub-G1 cell populations of CT-26 cells. The cells were treated with different concentrations $(2.5,5,10$ and $25 \mu \mathrm{M})$ of calenduloside E 6 '-methyl ester for $12 \mathrm{~h}$, and the DNA content was measured using a flow cytometer after staining with PI. (D) Three independent experiments of (C) were performed and data are shown as a bar diagram. CEME, calenduloside E 6'-methyl ester; FITC, fluorescent dye fluorescein isothiocyanate; PI, propidium iodide.

ester-treated cells and increased in a time-dependent manner. These results indicate that calenduloside E 6'-methyl ester induces apoptosis in CT-26 cells.

Calenduloside E 6'-methyl ester induced the activation of the caspase cascade. The activation of the caspase cascade was determined in CT-26 cells treated with $10 \mu \mathrm{M}$ calenduloside $\mathrm{E}$ 6'-methyl ester for the indicated times (3, 6, 9 and $12 \mathrm{~h})$. The amount of cleaved caspase-8 $(\sim 43 \mathrm{kDa})$ and caspase-3 $(\sim 19$ and $\sim 17 \mathrm{kDa}$ ) was increased by treatment with calenduloside $\mathrm{E}$ 6'-methyl ester (Fig. 3D). Calenduloside E 6'-methyl ester treatment caused a reduction in procaspase- $9(\sim 49 \mathrm{kDa})$ and induced cleavage of PARP. These results indicate that calenduloside E 6'-methyl ester induces apoptosis in CT-26 cells via the activation of the caspase cascade.

Calenduloside E 6'-methyl ester inhibited tumor growth in the CT-26 allograft colon carcinoma animal model. The anti-tumor activity of calenduloside E 6'-methyl ester was examined in a CT-26 colon carcinoma animal model using BALB/c mice. After 7 days subcutaneous implantation of CT-26 allograft, the average volumes of tumors were approximately $50 \mathrm{~mm}^{3}$. BALB/c mice were divided into groups and treated daily with a peritumor injection of calenduloside $\mathrm{E}$ 6'-methyl ester for 8 days. No acute side effects, including body weight loss, hair loss, lethargy and mortality, were detected (data not shown). In the control group, tumors grew rapidly and reached an average volume of $694.4 \pm 99.3 \mathrm{~mm}^{3}$ (mean \pm SE) on day 15 after inoculation with CT-26 cells (Fig. 4A). The size of the primary tumor $\left(313.74 \pm 33,214.3 \pm 42.5 \mathrm{~mm}^{3}\right)$ in 0.6 and $6 \mathrm{mg} / \mathrm{kg} /$ day calenduloside E 6'-methyl ester-treated animals was reduced to 45.2 and $30.9 \%$ of the control group size at 15 days, respectively. Similarly, the tumor weight for the 0.6 and $6 \mathrm{mg} / \mathrm{kg} /$ day calenduloside E 6'-methyl ester-treated group was reduced to 50 and $46 \%$ of the control group weight, respectively (Fig. 4B). Taken together, these results indicate 
A
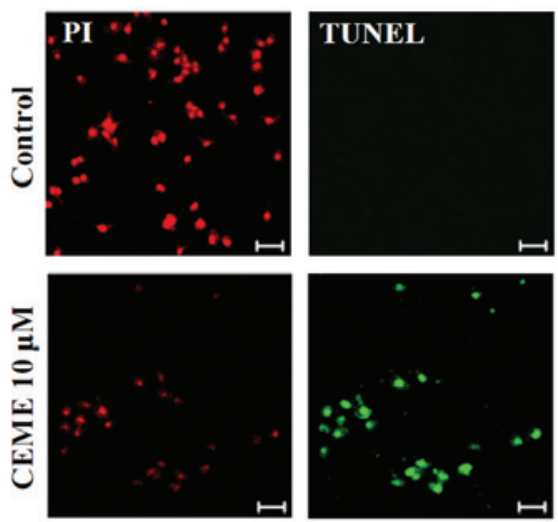

C

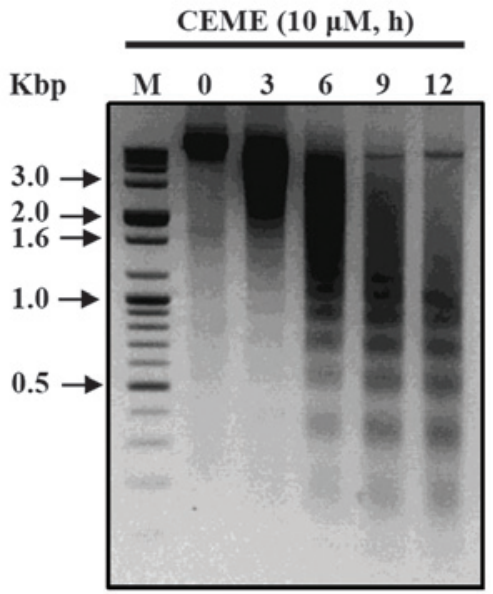

B
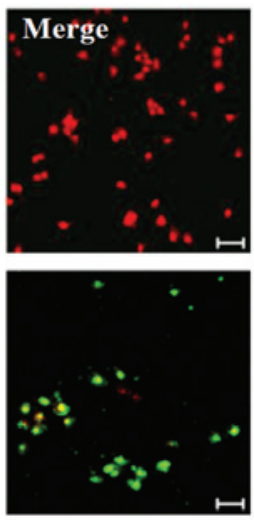

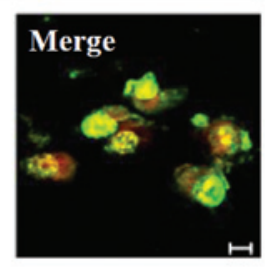

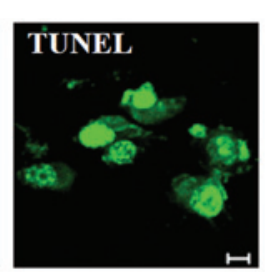

D
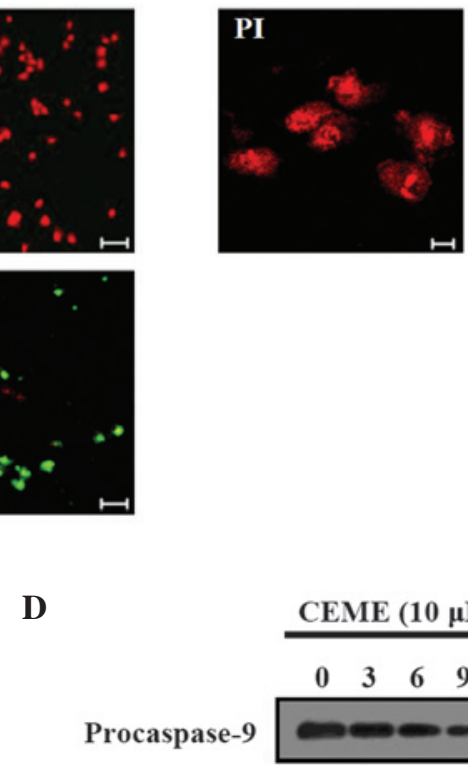

CEME (10 $\mu M$, h)

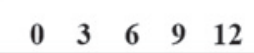

Cleaved caspase-8

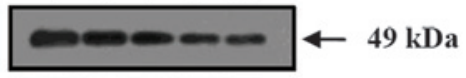

Cleaved caspase-3
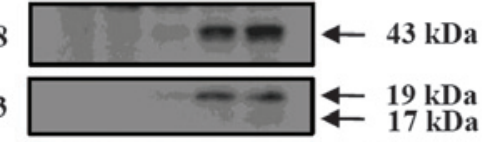

PARP

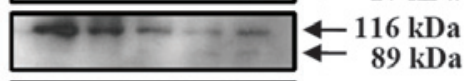

Actin

Figure 3. TUNEL, DNA fragmentation and caspase cascade analysis of calenduloside E 6'-methyl ester-treated CT-26 cells. (A) The intensity of fluorescein-dUTP labeling of DNA strand break was increased in calenduloside E 6'-methyl ester-treated CT-26 cells. Cells were treated with $10 \mu \mathrm{M}$ calenduloside E 6'-methyl ester for $12 \mathrm{~h}$. The cells were fixed, permeabilized and stained with enzyme buffer containing terminal deoxynucleotidyl transferase and fluorescein-dUTP. After nuclei staining with PI, cells were imaged at x 20 objective magnification using a confocal laser scanning microscope (bar, $50 \mu$ m). (B) Image of the TUNEL-stained cells of (A) is enlarged to better demonstrate the fluorescein signal (bar, $10 \mu \mathrm{m}$ ). (C) Calenduloside E 6'-methyl ester induced the DNA fragmentation of CT-26 cells. Cells were treated with $10 \mu \mathrm{M}$ calenduloside E 6'-methyl ester for the indicated times. DNA fragmentation was analyzed by agarose gel electrophoresis. M, 100 bp DNA ladder size markers. (D) Calenduloside E 6'-methyl ester induced the activation of caspase-8, $-3,-9$ and PARP. Protein extracts were prepared from CT-26 cells treated with $10 \mu \mathrm{M}$ calenduloside E 6'-methyl ester for the indicated times. The cleavage of caspase-3, -8, -9 and PARP were determined using western blot analysis. Actin was used as a control. CEME, calenduloside E 6'-methyl ester; TUNEL, terminal deoxynucleotidyl transferase mediated dUTP nick end labeling; PI, propidium iodine; PARP, poly ADP-ribose polymerase.

A

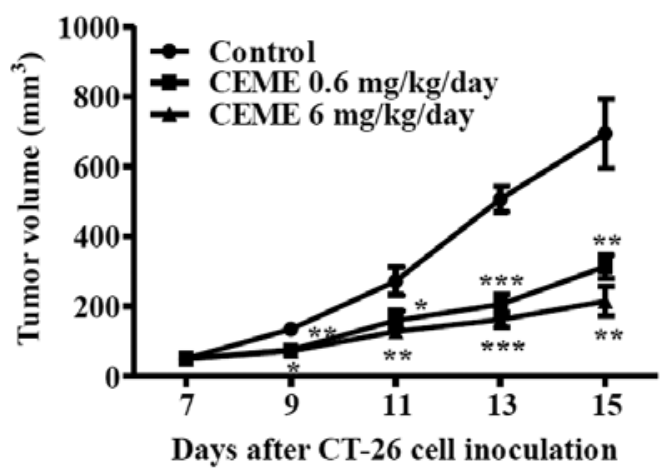

B

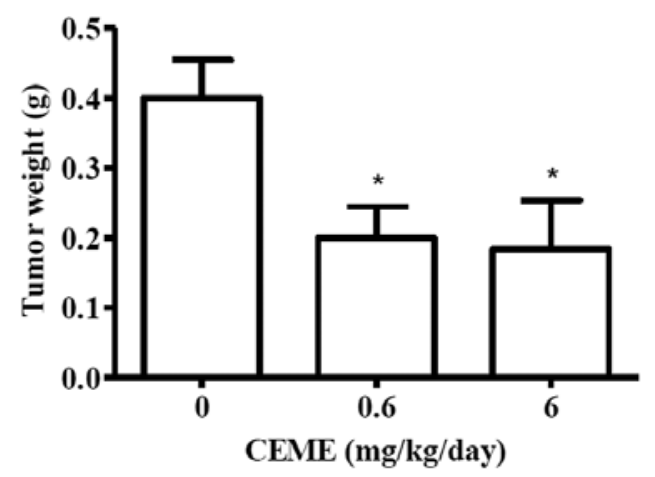

Figure 4. Effect of calenduloside E 6'-methyl ester on tumor growth in a CT-26 allograft colon carcinoma animal model. CT-26 cells (5x10 5 cells in $200 \mu 1$ PBS) were injected into the right flank of BALB/c mice. After the tumor was established (7 days; $50 \mathrm{~mm}^{3}$ ), the mice were treated daily with a peritumor injection of either calenduloside E 6'-methyl ester [0.6, $6 \mathrm{mg} / \mathrm{kg} /$ day in PBS with $0.2 \%$ DMSO (v/v)] or control (PBS with $0.2 \%$ DMSO) for 8 days. (A) Tumor volumes measured with a caliper are shown as a diagram. (B) Tumor weights after necropsy are shown as a bar diagram. Data are shown as the mean \pm SE. Statistically significant differences when compared with the control group were determined using the Student's t-test $\left({ }^{*} \mathrm{p}<0.05,{ }^{* *} \mathrm{p}<0.01,{ }^{* * *} \mathrm{p}<0.001\right)$. SE, standard error. 
that calenduloside E 6'-methyl ester inhibited tumor growth in the CT-26 allograft colon carcinoma animal model.

\section{Discussion}

Calenduloside E 6'-methyl ester, which is an oleanane-type triterpenoid, has been isolated from Brazilian ginseng, Pfaffia paniculata (13); however, its effects on colon cancer cells have not yet been reported. In this study, the cytotoxic effect of calenduloside E 6'-methyl ester isolated from Acanthopanax sessiliflorus fruits, was investigated in mouse colon carcinoma CT-26 cells. Calenduloside E 6'-methyl ester significantly decreased the cell viability of CT-26 cells when compared with its aglycone and parental structures, oleanolic acid and calenduloside E. When cells were treated with $10 \mu \mathrm{M}$ calenduloside E 6'-methyl ester for $24 \mathrm{~h}$, the viability of CT-26 cells decreased to approximately $50 \%$ relative to the untreated control cells. Oleanolic acid exhibits cytotoxic effects in a variety of cell lines, including A549 (non-small cell lung), SK-OV-3 (ovary), SK-MEL-3 (melanoma), XF498 (central nerve system), HCT15 (colon) and HONE-1 (nasopharyngeal carcinoma) (18-19). However, the oleanolic acid slightly decreased the viability of CT-26 cells at concentrations of 20 and $25 \mu \mathrm{M}$. The cytotoxic effect was not observed in $10 \mu \mathrm{M}$ oleanolic acid-treated CT-26 cells. Calenduloside E also inhibited the viability of CT-26 cells. However, the $\mathrm{ID}_{50}$ of calenduloside $\mathrm{E}$ was higher than that of calenduloside E 6'-methyl ester. Therefore, these results suggest that the presence of glucoronopyranoside or glucoronopyranoside-6'-methyl ester in C-3 position contributes to the cytotoxic activity of oleanolic acid derivatives. Notably, our findings on a high cytotoxic activity of calenduloside $\mathrm{E}$ 6'-methyl ester compared to calenduloside $\mathrm{E}$ are in accordance with a previous study which demonstrated that CDDO-Me exhibits more activity than CDDO against cancer cells due to the presence of the methyl ester group (20).

To confirm that the cytotoxic effect of calenduloside $\mathrm{E}$ 6 '-methyl ester was induced by apoptosis, calenduloside E 6'-methyl ester-treated CT-26 cells were characterized by detections of cell surface annexin-V and sub-G1 apoptotic cell populations, TUNEL and DNA fragmentation experiments. Calenduloside E 6'-methyl ester increased the cells immunostained with annexin-V-FITC and sub-G1 apoptotic cell populations (Fig. 2). It also increased terminal deoxynucleotidyl transferase dUTP nick end-labeled CT-26 cells (Fig. 3A and B) and induced DNA fragmentation (Fig. 3C). Taken together, these indicate that calenduloside E 6'-methyl ester induced apoptosis in CT-26 cells and treatment with Calenduloside E 6'-methyl ester resulted in the reduction of procaspase-9 and the increase of cleaved caspase-8 (Fig. 3D). Thus, calenduloside E 6'-methyl ester-induced apoptosis is mediated by the activation of the caspase cascade which is involved in apoptotic mechanisms (21,22). Calenduloside E 6'-methyl ester activates two major apoptotic signaling pathways, intrinsic and extrinsic, as is the case for other reported triterpenoids to induce apoptosis through mitochondria-mediated intrinsic and death receptorinduced extrinsic pathways (23).

Furthermore, we investigated the anti-tumor activity of calenduloside E 6'-methyl ester in a CT-26 colon carcinoma animal model using BALB/c mice. Calenduloside E 6'-methyl ester markedly reduced the tumor size and weight without acute side effects, including body weight loss, hair loss, lethargy and mortality. This is, to the best of our knowledge, the first study demonstrating that calenduloside E 6'-methyl ester inhibits tumor growth in a CT-26 colon carcinoma animal model.

In conclusion, our results demonstrated for the first time that calenduloside E 6'-methyl ester induces apoptosis and inhibits tumor growth in mouse colon carcinoma CT-26 in vitro and in vivo. Moreover, it induced apoptosis in CT-26 cells, which is mediated by extrinsic and intrinsic apoptotic signaling pathways, and inhibited tumor growth in a CT-26 colon carcinoma animal model. These findings suggest that calenduloside E 6'-methyl ester of Acanthopanax sessiliflorus fruits is a good source of chemotherapeutic agents involved in the inhibition of tumor growth.

\section{Acknowledgements}

This study was supported by grants from the Basic Science Research Program through the National Research Foundation of Korea (NRF) funded by the Ministry of Education, Science and Technology (20110003112), and from Kyung Hee University in 2010 (KHU-20110257).

\section{References}

1. Kristó TS, Terdy PP, Simándi B, Szöke E, Lemberkovics E and Kéry A: Efficiency of supercritical fluid extraction for the production of non-volatile terpenoids from Taraxaci radix. Acta Pharm Hung 71: 318-324, 2001.

2. Brieskorn CH and Süss HP: Triterpenoids from the peels of pear and apple. Arch Pharm 307: 949-960, 1974.

3. Urech K, Scher JM, Hostanska K and Becker H: Apoptosis inducing activity of viscin, a lipophilic extract from Viscum album L. J Pharm Pharmacol 57: 101-109, 2005.

4. Petronelli A, Pannitteri G and Testa U: Triterpenoids as new promising anticancer drugs. Anticancer Drugs 20: 880-892, 2009.

5. Konoshima T, Takasaki M, Tokuda H, Masuda K, Arai Y, Shiojima $\mathrm{K}$ and Ageta $\mathrm{H}$ : Anti-tumor-promoting activities of triterpenoids from ferns. I. Biol Pharm Bull 19: 962-965, 1996.

6. Nishino H, Nishino A, Takayasu J, Hasegawa T, Iwashima A, Hirabayashi K, Iwata S and Shibata S: Inhibition of the tumorpromoting action of 12-O-tetradecanoylphorbol-13-acetate by some oleanane-type triterpenoid compounds. Cancer Res 48: 5210-5215, 1998

7. Ryu SY, Oak MH, Yoon SK, Cho DI, Yoo GS, Kim TS and Kim KM: Anti-allergic and anti-inflammatory triterpenes from the herb of Prunella vulgaris. Planta Med 66: 358-360, 2000.

8. Honda T, Rounds BV, Gribble GW, Suh N, Wang Y and Sporn MB: Design and synthesis of 2-cyano-3,12-dioxoolean1,9-dien-28-oic acid, a novel and highly active inhibitor of nitric oxide production in mouse macrophages. Bioorg Med Chem Lett 8: 2711-2714, 1998

9. Honda T, Rounds BV, Bore L, Favaloro FG Jr, Gribble GW, Suh N, Wang Y and Sporn MB: Novel synthetic oleanane triterpenoids: a series of highly active inhibitors of nitric oxide production in mouse macrophages. Bioorg Med Chem Lett 9: 3429-3434, 1999.

10. Assefa H, Nimrod A, Walker L and Sindelar R: Synthesis and evaluation of potential complement inhibitory semisynthetic analogs of oleanolic acid. Bioorg Med Chem Lett 9: 1889-1894, 1999.

11. Konopleva M, Tsao T, Ruvolo P, Stiouf I, Estrov Z, Leysath CE, Zhao S, Harris D, Chang S, Jackson CE, Munsell M, Suh N, Gribble G, Honda T, May WS, Sporn MB and Andreeff M: Novel triterpenoid CDDO-Me is a potent inducer of apoptosis and differentiation in acute myelogenous leukemia. Blood 99: 326-335, 2002.

12. Yamaguchi Y, Yamada K, Yoshikawa N, Nakamura K, Haginaka J and Kunitomo M: Corosolic acid prevents oxidative stress, inflammation and hypertension in SHR/NDmcr-cp rats, a model of metabolic syndrome. Life Sci 79: 2474-2479, 2006. 
13. Li J, Jadhav AN and Khan IA: Triterpenoids from Brazilian ginseng, Pfaffia paniculata. Planta Med 76: 635-639, 2010.

14. Hahn DR, Kim CJ and Kim JH: A study on chemical constituents of Acanthopanax koreanum Nakai and its pharmaco-biological activities. Yakhak Hoeji 29: 357-361, 1985.

15. Yook CS, Rho YS, Sed SH, Leem JY and Han SH: Chemical components of Acanthopanax divaricatus and anticancer effect in leaves. Yakhak Hoeji 40: 251-261, 1996.

16. Fujikawa T, Yamaguchi A, Morita I, Takeda H and Nihshibe S: Protective effects of Acantopanax senticosus Harms from Hokkai do and its components on gastric ulcer in restrained cold water stressed rats. Biol Pharm Bull 19: 1227-1230, 1996.

17. Alessandria G, Filippeschi S, Sinibaldi P, Mornet F, Passera P, Spreafico F, Cappa PM and Gullino PM: Influence of gangliosides on primary and metastatic neoplastic growth in human and murine cells. Cancer Res 47: 4243-4247, 1987.
18. Chiang YM, Chang JY, Kuo CC, Chang CY and Kuo YH: Cytotoxic triterpenes from the aerial roots of Ficus microcarpa. Phytochemistry 66: 495-501, 2005.

19. Kim YK, Yoon SK and Ryu SY: Cytotoxic triterpenes from stem bark of Physocarpus intermedius. Planta Med 66: 485-486, 2000

20. Deeb D, Gao X, Dulchavsky SA and Gautam SC: CDDO-me induces apoptosis and inhibits Akt mTOR and NF-kappa B signaling proteins in prostate cancer cells. Anticancer Res 27: 3035-3044, 2007.

21. Lowe SW and Lin AW: Apoptosis in cancer. Carcinogenesis 21: 485-495, 2000

22. Johnstone RW, Ruefli AA and Lowe SW: Apoptosis: a link between cancer genetics and chemotheraphy. Cell 108: 153-164, 2002.

23. Hengartner MO: The biochemistry of apoptosis. Nature 407: 770-776, 2000 